\title{
Narodowe strategie zwalczania nowotworów: doświadczenia, struktura, dobre praktyki
}

\author{
Adam Kozierkiewicz ${ }^{1}$, Jacek Jassem²
}

Polski system opieki onkologicznej wymaga opracowania kompleksowej strategii. W niniejszym opracowaniu przedstawiono przegląd strategicznych dokumentów dotyczących zwalczania nowotworów, które powstały w ostatniej dekadzie w innych krajach europejskich. Z analizy tych dokumentów wynika w szczególności, że 1) definiowanie strategii wymaga dobrego rozpoznania i diagnozy sytuacji, wraz z przyczynami niedomagań obecnego stanu, 2) należy dobrze zdefiniować cele strategiczne i rozróżnić je od planowanych działań, 3) konieczny jest jasny podział ról w realizacji strategii, 4) przydatne jest wskazanie zasobów, w tym finansowych, niezbędnych do realizacji strategii.

\section{National strategies for cancer control: the experiences, structure, good practice}

Polish system of oncological care necessitates the development of comprehensive strategy. This article reviews strategic cancer control documents, which were developed in the past decade in other European countries. Observation and analysis of the documents lead to following conclusions: 1) defining a strategy requires good assessment and diagnosis of the present situation, including detection of main causes of shortcomings, 2) the goals and objectives should be well defined and logically distinguished from actions, 3) there is a need for clear distribution of roles of different actors in the strategy execution, 4) it is useful to indicate resources, including financial resources, which are necessary in the strategy execution.

NOWOTWORY Journal of Oncology 2013; 63, 5: 368-374

Słowa kluczowe: zwalczanie nowotworów, strategia, zdrowie publiczne

Key words: cancer control, strategy, public health

\section{Wstęp}

Istnieje wiele definicji strategii, jak również wiele uzasadnień dla jej tworzenia. Strategie tworzone są dla różnych organizacji; dla przedsiębiorstw, instytucji publicznych, regionów, krajów czy nawet grup krajów i narodów. Historia oraz zręby koncepcji myślenia strategicznego oraz taktycznego tkwią w wojskowości i wynikają z konieczności skoordynowania działania wielu ludzi i ich zespołów w celu osiągnięcia zamierzonego celu.

Strategia wyraża długoterminowe cele organizacji ujętych w programy i plany, a także przedstawia alokację niezbędnych do ich realizacji zasobów [1]. Strategia stanowi również wzorzec decyzji dotyczących pozycji i tożsamości organizacji, jej zdolności do wykorzystywania swych możliwości oraz prawdopodobieństwa odniesienia sukcesu [2]. Strategie są najczęściej programami ogólnymi, ukierunkowanymi na możliwie pełne wykorzystanie potencjału danego systemu dla osiągnięcia założonych celów [3].

Orędownikami tworzenia strategii w obszarze zwalczania nowotworów są:Światowa Organizacja Zdrowia [4],Wspólnota Europejska [5] oraz międzynarodowe organizacje pozarządowe $[6,7]$.Z natury rzeczy strategia zwalczania nowotworów powinna się odnosić do wielu aspektów i dziedzin życia społecznego, a także do wielu organizacji i instytucji. Tym samym strategia taka powinna byćłącznikiem w zarządzaniu wielu podmiotów; wspólnym mianownikiem i spoiwem ich działalności.

${ }^{1}$ JASPERS, Eurpejski Bank Inwestycyjny*

${ }^{2}$ Katedra i Klinika Onkologii i Radioterapii

Gdański Uniwersytet Medyczny

*Opinie wyrażone przez autora w niniejszym materiale mają charakter osobisty i mogą nie odzwierciedlać stanowiska EIB 


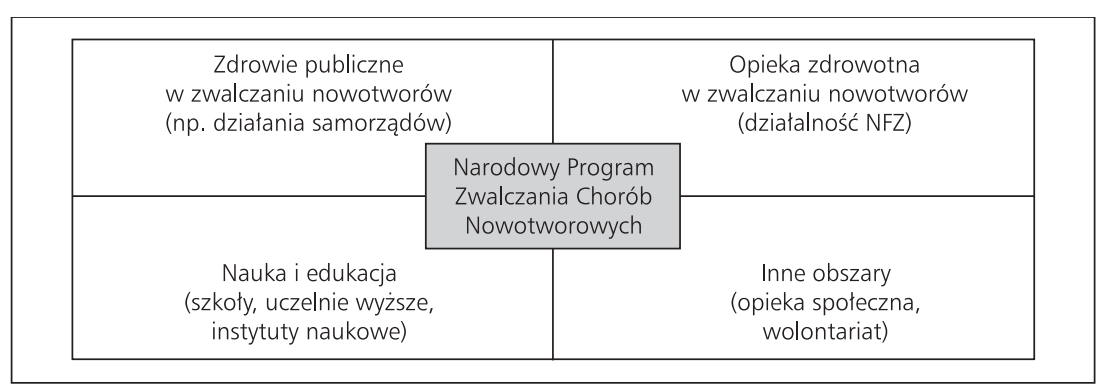

Rycina 1. Szeroka strategia zwalczania nowotworów oraz NPZChN jako element interwencyjny

Dyskusje prowadzone od kilku lat w środowisku polskich onkologów, pozarządowych organizacji pacjentów a także polityków prowadzą do wniosku, że polski system zwalczania nowotworów wymaga opracowania kompleksowej strategii. Strategia taka powinna być zorientowana na zwalczanie nowotworów, czyli działania z zakresu zapobiegania, wczesnego wykrywania, leczenia oraz zmniejszania skutków choroby (burden) związanych z nowotworami. Strategia powinna obejmować zadania systemu ochrony zdrowia, ale także takie obszary życia społecznego, jak edukacja, nauka czy inwestycje, które w pewnej perspektywie wpływają na zwalczanie nowotworów. Strategia powinna być drogowskazem odnośnie priorytetów dla władzy publicznej i wszystkich osób oraz organizacji mających wpływ na zwalczanie nowotworów, począwszy od służb nadzoru środowiskowego, sanitarno-epidemiologicznych, bezpieczeństwa i higieny pracy, poprzez diagnostykę i leczenie, aż po działalność opieki społecznej i systemu ubezpieczeń społecznych (w Polsce ZUS, KRUS).

W tym kontekście strategia zwalczania nowotworów jest czym innym niż obecnie realizowany Narodowy Program Zwalczania Chorób Nowotworowych (NPZCN). Zarządzany przez Ministerstwo Zdrowia NPZCN stworzony został i działał jako program interwencyjny, uzupełniający z dodatkowych środków z budżetu państwa najistotniejsze braki w systemie zwalczania nowotworów, takie jak badania przesiewowe czy niedobory aparatury do radioterapii. NPZCN nie wytyczał jednak kierunków dla wszystkich podmiotów, organizacji i instytucji zajmujących się zwalczaniem raka. To zadanie powinno być wypełniane w przyszłości przez strategię. Relację pomiędzy strategią a NPZCN przedstawiono na rycinie 1.

W niniejszym opracowaniu pojęcie „strategia zwalczania nowotworów" oznacza zatem program scharakteryzowany przez WHO [8] jako „program zdrowia publicznego, zaprojektowany w celu zmniejszenia zapadalności i umieralności z powodu chorób nowotworowych oraz poprawy jakości życia chorych na nowotwory, poprzez systematyczne i zrównoważone interwencje oparte na dowodach naukowych (EBM), obejmujące zapobieganie, wczesne wykrywanie, rozpoznawanie, leczenie i opiekę paliatywną, z najlepszym wykorzystaniem dostępnych zasobów".

\section{Doświadczenia europejskie w zakresie krajowych planów i strategii zwalczania nowotworów}

Istnieje wiele międzynarodowych doświadczeń dotyczących tworzenia i implementacji planów i strategii zwalczania nowotworów. Poszczególne organizacje międzynarodowe, z różnym mandatem, proponują także własne podejścia metodyczne do tworzenia strategii. Narodowe strategie lub plany zwalczania nowotworów mają różny charakter i pojęcia te zdecydowanie nie oznaczają jednorodnych tworów. Różne są także losy, w tym efekty takich planów.

Z raportu Imperial College w Londynie wynika, że w roku 2009 spośród 27 państw Europy objętych analizą, 16 posiadało strategie lub narodowe plany zwalczania raka. Te państwa to:

- Belgia (B)

- Dania (DK)

- Anglia (EN), Walia (C), Szkocja (CAL), Irlandia Północna (N IRL)

- Estonia (EE)

- Francja (F)

- Węgry $(\mathrm{H})$

- Irlandia (IRL)

- Włochy (I)

- Polska (PL) (tutaj uwzględniono NPZChN)

- Litwa (LT)

- Malta (MT)

- Holandia $(\mathrm{H})$

- Norwegia (N)

- Portugalia $(\mathrm{P})$

- Hiszpania (E)

- Szwajcaria $(\mathrm{CH})$

\section{Podsumowanie zawartości planów}

1. W większości przypadków analizowanych strategii i planów ich zawartość można podzielić na następujące kategorie:
a) analiza obecnej sytuacji,
b) cele: główny i szczegółowe,
c) zadania i rekomendacje,
d) finansowanie, ich źródła i szacowane wielkości, 
e) mierzalne wskaźniki i docelowe wartości,

f) harmonogram.

Jedynie polski plan nie zawierał analizy sytuacji, za to jako jedyny miał postać aktu prawnego.

2. Wszystkie plany miały jasno zdefiniowane cele, zwykle w postaci ograniczenia zapadalności na niektóre nowotwory, zmniejszenia umieralności, poprawy jakości życia chorych oraz osób po przebytej chorobie, zmniejszenia nierówności w dostępie do leczenia oraz poprawy skuteczności i ekonomicznej efektywności leczenia.

3. Organizacja systemu zwalczania nowotworów na poziomie makro zajmuje ważną rolę $w$ analizowanych strategiach. W części analizowanych programów zakładano zmiany w organizacji istniejących ,sieci zwalczania nowotworów" (B, DK, EN, F, I, N, IRL), w większości daleko idące. Rola tych sieci bywała różnorodna; głównie miała polegać na dostarczaniu optymalnej jakości usług przez wykwalifikowane i doświadczone zespoły. W EN jednak tę rolę, zgodnie z logiką National Health Service, postanowiono rozszerzyć na nabywanie świadczeń (rola koordynatora). Podobnie koordynacyjną rolę przypisywano sieci w DK, choć bez wskazywania szczegółów.

4. Instytucje nadzorujące realizację planu były wskazywane w 11 krajach, w tym w 6 postanowiono stworzyć nowe instytucje (w tym w PL). Instytucje nadzorujące miały zwykle charakter komisji złożonych z przedstawicieli kluczowych interesariuszy systemu, działających przy organach administracji rządowej lub regionalnej (w P).

5. Poprawa funkcjonowania krajowych rejestrów nowotworów była wskazywana w prawie wszystkich programach, a w krajach, w których taki rejestr nie działał (B, IRL), zapowiadano jego uruchomienie. Jednocześnie wskazywano, że rolą rejestrów jest śledzenie postępów w zwalczaniu nowotworów, w tym wychwytywaniu działań, które są skuteczne i nieskuteczne. Rejestry mają pomagać w planowaniu działań, określeniu potrzebnej liczby ośrodków i usług w onkologii oraz pozwalać na międzyregionalne i międzynarodowe porównania skuteczności leczenia.

6. W analizowanych planach 9 państw określało sumy przeznaczane na realizowanie planu (w tym w czterech były to kwoty finansowane ze środków centralnych, m.in. w PL). Kwoty te stanowiły jednak niewielki ułamek wszystkich środków wydawanych na zwalczanie nowotworów (np. w B $380 \mathrm{mln} €$ w ciągu 3 lat w porównaniu z ok. 1,5 mld rocznie wydatków na leczenia nowotworów). Środki wykazane w planach miały przeznaczenie interwencyjne: obejmowały uzupełnienie wyposażenia w sprzęt, finansowanie szczególnych leków (np. w B: bewacyzumabu), szkolenie personelu, programy badań przesiewowych, rozwój rejestrów nowotworowych, badania i rozwój.
7. W działaniach interwencyjnych dotyczących zdrowia publicznego wskazywano najczęściej na:

a) profilaktykę pierwotną, głównie poprzezograniczenie zachowań szkodliwych dla zdrowia, takich jak palenie tytoniu, nadużywanie alkoholu, niewłaściwa dieta, brak aktywności fizycznej, narażenie na promienie słoneczne, czynniki związane ze środowiskiem pracy;

b) profilaktykę wtórną - badania przesiewowe raka piersi i szyjki macicy (we wszystkich krajach), jelita grubego (w 10 z 19).

8. Zmiany w systemie dostarczania świadczeń, głównie poprzez:

a) centralizację leczenia chirurgicznego w celu osiągnięcia odpowiedniego doświadczenia zespołów zabiegowych;

b) zaangażowanie lekarzy rodzinnych, głównie na etapie promocji zdrowia, wspomagania powszech ności badań przesiewowych, wczesnego wykrywania oraz opieki po leczeniu;

c) wielospecjalistyczną opiekę (we wszystkich krajach) wraz z rolą koordynatora, głównie dla pielęgniarek klinicznych, zapewniających ciągłość opieki i sprawne przechodzenie przez jej poszczególne etapy;

d) w 13 krajach (z wyjątkiem LT, PL i P) — stworzenie sieci placówek współpracujących w procesie opieki nad chorymi na raka; w DK, F i EE — jako sieci lekarzy rodzinnych i szpitali, w pozostałych krajach — jako sieci wielu placówek zarządzanych z poziomu regionu;

e) poprawę wczesnego wykrywania i sprawnego przechodzenia chorego pomiędzy fazami opieki. W DK narzędziem do uzyskania tego efektu są systemy IT, wspomagające procesy kliniczne (clinical pathways), zapewniające właściwe planowanie i przepływ informacji;

f) dostępność rehabilitacji i opieki paliatywnej, wraz z multidyscyplinarnym podejściem do tej opieki;

g) dostępność innowacyjnych technologii (lekowych i nielekowych) - w 14 krajach, w tym zakupy nowoczesnego sprzętu diagnostycznego (CT, MRI, PET) czy terapeutycznego (przyspieszacze liniowe);

h) w 9 krajach - wzmocnienie stosowania zaleceń klinicznych opartych na EBM, opracowywanych na poziomie kraju lub lokalnie. W szczególności zalecenia te miały dotyczyć wyboru terapii lekowych oraz prowadzenia badań przesiewowych.

9. Zapewnienie jakości wymieniane było we wszystkich planach:

a) akredytację placówek prowadzących leczenie nowotworów proponowano w 8 krajach. W IRL proponowano akredytację oraz licencjonowanie;

b) wszystkie kraje planowały poprawę jakości opieki, a 12 z nich, w tym Polska - uruchomienie systemu 
Tabela I. Klasyczne elementy podlegające ocenie w kontekście nowotworów

\begin{tabular}{|c|c|}
\hline Populacja & Przedmiot oceny \\
\hline Populacja ogólna & $\begin{array}{l}\text { Powiązanie nowotworów (zapadalności, umieralności i in.) z cechami socjoekonomicznymi } \\
\text { Dane demograficzne i prognozy } \\
\text { Liczba zdrowych } \\
\text { Poziom świadomości zagrożenia chorobą nowotworową i wpływu czynników ryzyka }\end{array}$ \\
\hline $\begin{array}{l}\text { Populacja obarczona czynnikami ryzyka (tytoń, } \\
\text { alkohol, otyłość, niska aktywność fizyczna i in.) }\end{array}$ & $\begin{array}{l}\text { Liczba palaczy tytoniu (i in.) i tendencje palenia (i in. czynników ryzyka) } \\
\text { Wiek, płeć } \\
\text { Rozkład terytorialny, społeczny }\end{array}$ \\
\hline Populacja z nowo wykrytym nowotworem & $\begin{array}{l}\text { Występowanie nowotworów, w szczególności wyleczalnych dzięki wczesnemu wykrywaniu } \\
\text { Stadium kliniczne w chwili wykrycia i jego determinanty } \\
\text { Świadomość dotycząca programów przesiewowych i ich skuteczność } \\
\text { Umieralność, jej rozkład w populacji i determinanty }\end{array}$ \\
\hline Osoby po przebyciu choroby nowotworowej & $\begin{array}{l}\text { Przeżycia w przebiegu choroby nowotworowej i ich determinanty } \\
\text { Liczba powikłań w przebiegu choroby } \\
\text { Liczba chorych z przerzutami } \\
\text { Jakość życia w chorobie i po jej zakończeniu } \\
\text { Skutki i potrzeby socjoekonomiczne związane z chorobą }\end{array}$ \\
\hline Zgony z powodu nowotworów & Umieralność; liczba i wskaźniki \\
\hline
\end{tabular}

Źródło: na podstawie WHO [12]

monitorowania jakości. W 7 krajach planowano wprowadzenie krajowych standardów postepowania i stworzenie na tej podstawie systemu monitorowania jakości;

c) w 4 krajach wskazywano na konieczność poprawy jakości rehabilitacji i opieki paliatywnej.

10. We wszystkich krajach planowano działania na rzecz kształcenia personelu medycznego na różnych etapach, od przeddyplomowego do specjalistycznego. Pięć krajów planowało specjalne szkolenia dla personelu pomocniczego, który miałby wspomagać proces opieki nad chorym.

11. Badania naukowe były wymieniane jako immanentna część działalności systemu w 15 krajach.

Już po opracowaniu raportu Imperial College kolejne kraje europejskie (Cypr, Czechy, Grecja, Finlandia, Łotwa i Słowenia) ogłosiły swoje strategie. Treści i akcenty zawarte w tych planach nie odbiegały od wcześniej przedstawionych [6]. Istniejące dane pozwalają zatem na pewne podsumowanie i określenie głównych zaleceń dotyczących wewnętrznej struktury i kluczowych treści narodowych strategii zwalczania raka.

\section{Wytyczne dotyczące tworzenia narodowych strategii zwalczania nowotworów}

Dobre praktyki stosowane przy tworzenia strategii dla różnych rodzajów organizacji są szeroko opisywane [3, 9-11] i względnie dobrze znane. W odniesieniu do strategii zdrowotnych można wyróżnić pewną pulę szczególnych cech, a wobec problemu zwalczania nowotworów cechy te stają się jeszcze bardziej charakterystyczne. W niniejszym opracowaniu znajdują się cechy i elementy strategicznych dokumentów oraz procesów ich tworzenia, zalecane przez Światową Organizację Zdrowia [8, 12], Komisję i Parlament Europejski [5], a także ośrodki eksperckie [6, 13, 29].
W procesie definiowania strategii należy wyróżnić trzy zasadnicze etapy, których efektem są trzy generalne części strategii:

1. Ocena obecnego stanu (Gdzie jesteśmy?),

2. Wskazanie docelowego stanu (Gdzie chcemy być?),

3. Wskazanie działań, które mają doprowadzić do docelowego stanu (Jak się tam dostać?).

\section{Ocena obecnego stanu}

Szczegółowość opisu obecnego stanu zależy od możliwości i zasobów systemu informacyjnego danego kraju, przy uwzględnieniu, że istnieją różne instytucje gromadzące dane, często niebezpośrednio związane z nowotworami.

Klasyczne elementy podlegające ocenie w kontekście nowotworów zawarte są $w$ tabeli I.

Liczbowe dane są podstawą, lecz nie wyczerpują pojęcia oceny. Konieczne jest dodanie do niej projekcji najważniejszych zmian w przyszłości. Jej stałym elementem w zakresie chorób nowotworowych jest uwzględnienie przewidywanych zmian demograficznych. Starzenie się populacji powoduje naturalną tendencję do wzrostu liczby zachorowań na choroby nowotworowe. Na ten proces nakładają się jednak także inne czynniki, w tym zmiany zachowań, które mogą zmniejszać ryzyko zachorowań (np. spadek liczby osób palących tytoń).

Dla celów sformułowania strategii konieczna jest także interpretacja danych opisujących obecny stan i wskazanie, w jakich obszarach możliwa jest jego poprawa. Może ona, co do zasady, występować w każdym analizowanym obszarze; od zmniejszenia ekspozycji na czynniki ryzyka i tym samym ograniczenia zapadalności, poprzez wczesne wykrywanie, prowadzące do lepszych wyników leczenia, jak też poprawę jakości życia chorych w trakcie leczenia i po jego zakończeniu. Zidentyfikowanie obszarów i możliwości poprawy stanowi podstawę do sformułowania kierunków zmian. 
Ocena obecnego stanu obejmuje także instytucjonalną i polityczną analizę, której celem jest wskazanie środowisk i organizacji działających w szeroko zdefiniowanym systemie zwalczania nowotworów, wraz z charakterystyką ich interesów i wzorców zachowań. Ta analiza, w szczególności z wykorzystaniem narzędzi do symulacji procesów politycznych [15], powinna pomóc w skutecznym budowaniu wsparcia dla planowanych zmian.

\section{Wskazanie docelowego stanu}

Wskazanie docelowego stanu jest kluczową składową definiowania strategii. Na podstawie oceny obecnego stanu trzeba określić działania, które należy podejmować przez kolejne lata, oraz określić ich cele. Pozwala to zakomunikować wszystkim uczestnikom procesu, jaki będzie ich ostateczny efekt podjętych działań [16]. Brak celów lub ich niejasne sformułowanie powodują, że uczestnicy procesu nie znają celów poszczególnych działań oraz nie rozumieją związanego z tym wysiłku i ewentualnych niewygód. Błędem jest założenie, że jednakowo rozumieją oni misję systemu i jego składowych, jego główne oraz szczegółowe cele. Komunikowanie celów przedsięwzięć i zyskanie dla nich środowiskowego poparcia jest podstawowym zadaniem lidera zmian. Dla wielu uczestników właśnie znajomość jasno zdefiniowanych celów może się stać głównym napędem i motywacją do wysiłku.

Definiowanie celów strategii najczęściej obejmuje określenie celu głównego (goals, aims) oraz celów szczegółowych, operacyjnych (objectives). Do celów szczegółowych na pewnym etapie dołączane są omówione w następnym podrozdziale działania (actions), które mają służyć ich osiąganiu. Przy definiowaniu celów należy uwzględnić ograniczone możliwości ludzkiej percepcji. Psychologowie, a za nimi specjaliści ds. marketingu lub zarządzania posługują się „regułą siedmiu", oznaczającą, że człowiek jest w stanie równolegle sprawnie uczestniczyć w 5-9 tematach [16]. Oznacza to, że liczba celów głównych, a następnie szczegółowych, podporządkowanych głównym, powinna być mniejsza niż 9.

Cel główny powinien wskazywać cele realizacji całej strategii. W przypadku tak szerokich działań jak „zwalczanie nowotworów" brzmienie celu głównego jest także szerokie i ogólne, lub w brzmieniu celu głównego zawarte są przedstawione niżej cele szczegółowe.

Przykłady celów głównych:

- Dania:„,Wzmocnienie działań na rzecz zapobiegania nowotworom oraz zapewnienie chorym możliwości wczesnego rozpoznania i wdrożenia leczenia, postrzeganych przez pacjentów jako spójne oraz odpowiadające najwyższym międzynarodowym standardom".

- Anglia: „ocalenie większej liczby istnień ludzkich, poprawa jakości życia chorych, zmniejszenie nierówności, dostarczenie opieki w najlepszym miejscu i najlepszym czasie, przy uwzględnieniu poniesionych nakładów".
- Francja: „obniżenie umieralności z powodu raka o 20\% w ciągu 5 lat. Plan ma wpłynąć na cały system ochrony zdrowia, z nową wizją, w której z nowotworami walczą chorzy, ich rodziny i przyjaciele, a także lekarze i pielęgniarki".

Cele szczegółowe służą sprecyzowaniu celu głównego, choć powyższe przykłady pokazują, że czasem w treści celu głównego zawarte są już cele szczegółowe. Dobrą praktyką jest definiowanie celów szczegółowych, z uwzględnieniem formuły SMART [12] oznaczającej, że powinny one być:

- odpowiednio szczegółowo sprecyzowane (specific),

- dające się zmierzyć (measurable),

- możliwe do osiągnięcia (achievable),

- adekwatne do kontekstu (relevant),

- umiejscowione w czasie (time adjusted).

W odniesieniu do strategii zwalczania nowotworów cele szczegółowe najczęściej dotyczą:

- ograniczenia liczby zachorowań w wyniku ograniczenia czynników ryzyka;

- wczesnego wykrywania i tym samym zwiększania szansy na wyleczenie;

- skutecznego leczenia, co oznacza wdrożenie procesu diagnostyczno-terapeutycznego zgodnego z aktualną wiedzą medyczną, skoordynowanego, realizowanego w odpowiednim czasie (bez opóźnień) oraz przez odpowiedni personel, co zwiększa szanse wyleczenia;

- utrzymania wysokiej jakości życia w trakcie oraz po zakończeniu leczenia;

- osiągania powyższych celów w sposób efektywny kosztowo.

Cele szczegółowe mogą być mierzalne przy użyciu określonych wskaźników lub mogą być tożsame z mierzalnym stanem docelowym (targets). W obu przypadkach oznacza to, że znając stan wyjściowy, można go zmierzyć i określić ilościowo docelowy efekt.

Typowym przykładem jest zapadalność, mierzona wskaźnikiem zapadalności (najlepiej z uwzględnieniem wieku i płci). Zapadalność może się obniżać, najczęściej poprzez zmniejszenie czynników ryzyka (np. zapadalność na raka płuca w wyniku zmniejszenia narażenia na palenie tytoniu). Cele szczegółowe można tym samym przedstawić w postaci liczbowej, np. „zmniejszenie o 20\% zapadalności na raka płuca w ciągu 10 lat".

\section{Wskazanie działań służq̨cych osiągnięciu celu}

Podobnie jak „,reguła siedmiu" ogranicza liczbę równolegle przedstawianych komunikatów dotyczących celów, tak „reguła trzech" ogranicza liczbę poziomów komunikatów. Cele szczegółowe, odnoszące się do poszczególnych celów głównych, stanowią drugi poziom. Aby nie napotykać problemów z czytelnością przekazu, obok celów szczegółowych warto rozważyć jeszcze tylko jeden, trzeci poziom uszczegółowienia komunikatu (ryc. 2). Można go 


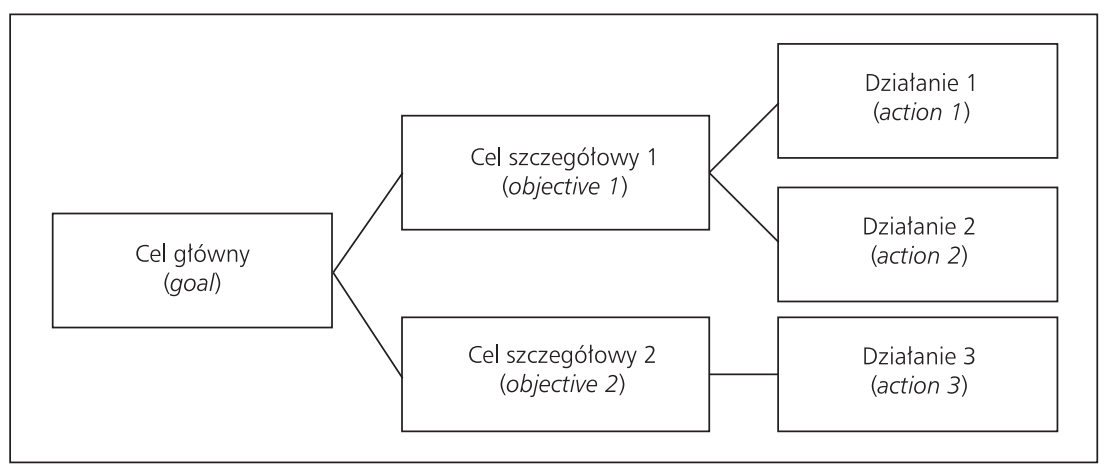

Rycina. 2. Relacja celów głównych, szczegółowych i działań

Tabela II. Przykłady działań w strategiach zwalczania raka w zależności od zamożności kraju

\begin{tabular}{|c|c|c|c|}
\hline $\begin{array}{l}\text { Kategoria } \\
\text { i zakres }\end{array}$ & Podstawowy & Poszerzony & Pożądany \\
\hline Zapobieganie & $\begin{array}{l}\text { Promocja dobrych wzorców zachowań, } \\
\text { w tym: } \\
\text { - zdrowej diety, aktywności fizycznej, } \\
\text { bezpiecznego życia seksualnego, karmienia } \\
\text { piersią } \\
\text { - niepalenia tytoniu, umiarkowanego } \\
\text { picia alkoholu i korzystania ze słońca } \\
\text { Implementacja Konwencji ws. Kontroli } \\
\text { Wyrobów Tytoniowych } \\
\text { Wprowadzenie regulacji bezpieczeństwa } \\
\text { i higieny pracy } \\
\text { Wdrożenie szczepień przeciw HBV }\end{array}$ & $\begin{array}{l}\text { Poszerzenie legislacji } \\
\text { antytytoniowej, antyalkoholowej, } \\
\text { BHP } \\
\text { Uruchomienie programów } \\
\text { zapobiegania chorobom } \\
\text { przewlekłym } \\
\text { Wprowadzenie niskokosztowych } \\
\text { usług promocji zdrowia (porad } \\
\text { lekarzy POZ, medycyny szkolnej, } \\
\text { medycyny pracy w zakresie } \\
\text { np. palenia tytoniu, otyłości itp.) }\end{array}$ & $\begin{array}{l}\text { Wzmocnienie wszechstronnych } \\
\text { programów promocji zdrowia, } \\
\text { opartych na EBM, realizowanych } \\
\text { międzysektorowo } \\
\text { Wprowadzenie rutynowych } \\
\text { pomiarów nasilenia czynników } \\
\text { ryzyka }\end{array}$ \\
\hline Wczesne rozpoznanie & $\begin{array}{l}\text { Szerzenie wiedzy o wczesnych objawach } \\
\text { nowotworów } \\
\text { Udostępnienie niskokosztowych badań } \\
\text { przesiewowych (np. w kierunku raka szyjki } \\
\text { macicy) }\end{array}$ & $\begin{array}{l}\text { Zapewnienie badania } \\
\text { przesiewowego w kierunku raka } \\
\text { szyjki macicy dla min. } 70 \% \text { kobiet } \\
\text { w wieku powyżej } 35 \text { lat } \\
\text { Zapewnienie badania palpacyjnego } \\
\text { piersi przez personel medyczny co } \\
1-2 \text { lata dla kobiet w wieku powyżej } \\
40 \text { lat } \\
\text { Rozwijanie systemu centrów } \\
\text { szkoleniowych oraz systemów } \\
\text { monitorowania jakości dla programów } \\
\text { wczesnego wykrywania raka }\end{array}$ & $\begin{array}{l}\text { Zapewnienie badania szyjki macicy } \\
\text { co } 3 \text { lata dla } 70 \% \text { kobiet w wieku } \\
\text { powyżej } 25 \text { lat } \\
\text { Zapewnienie badania } \\
\text { mammograficznego co } 2 \text { lata dla } \\
70 \% \text { kobiet w wieku powyżej } 50 \text { lat } \\
\text { Zapewnienie badania na krew } \\
\text { utajona (rak jelita grubego) co } 2 \text { lata } \\
\text { dla } 70 \% \text { populacji w wieku powyżej } \\
50 \text { lat }\end{array}$ \\
\hline $\begin{array}{l}\text { Rozpoznawanie } \\
\text { i leczenie }\end{array}$ & $\begin{array}{l}\text { Zapewnienie rozpoznawania i leczenia } \\
\text { najczęstszych nowotworów wg } \\
\text { standaryzowanych protokołów } \\
\text { Zapewnienie rozpoznawania i leczenia } \\
\text { raka szyjki macicy dla wszystkich kobiet } \\
\text { z nowotworem wykrytym w badaniu } \\
\text { przesiewowym }\end{array}$ & $\begin{array}{l}\text { Zapewnienie rozpoznawania } \\
\text { i leczenia oraz rehabilitacji chorych } \\
\text { na wszystkie nowotwory, łącznie } \\
\text { z rozsianymi, o ile rokują wyleczenie } \\
\text { lub istotne przedłużenie życia (wg } \\
\text { standaryzowanych protokołów) } \\
\text { Rozwijanie systemu centrów } \\
\text { szkoleniowych oraz systemów } \\
\text { monitorowania jakości dla } \\
\text { najczęstszych nowotworów }\end{array}$ & $\begin{array}{l}\text { Wzmocnienie sieci ośrodków } \\
\text { wielodyscyplinarnego leczenia raka } \\
\text { działających w obszarze szkolenia, } \\
\text { badań, w tym wspieranie krajowych } \\
\text { i międzynarodowych centrów } \\
\text { Umożliwienie prowadzenia badań } \\
\text { klinicznych dla nowych metod } \\
\text { leczenia }\end{array}$ \\
\hline Opieka paliatywna & $\begin{array}{l}\text { Zapewnienie ochrony przed bólem, } \\
\text { głównie w trybie domowym } \\
\text { Zrównoważona polityka dostępu do leków } \\
\text { opioidowych } \\
\text { Rozwój ośrodków szkolących dla personelu } \\
\text { POZ i służb społecznych }\end{array}$ & $\begin{array}{l}\text { Zapewnienie opieki paliatywnej } \\
\text { na wszystkich poziomach opieki } \\
\text { wg standardowych protokołów } \\
\text { Zapewnienie dostępu do } \\
\text { niezbędnych leków na terenie } \\
\text { całego kraju } \\
\text { Zapewnienie szkolenia przed- } \\
\text { i podyplomowego w zakresie opieki } \\
\text { paliatywnej }\end{array}$ & $\begin{array}{l}\text { Wzmocnienie sieci ośrodków opieki } \\
\text { paliatywnej } \\
\text { Rozwój referencyjnych ośrodków } \\
\text { opieki paliatywnej }\end{array}$ \\
\hline
\end{tabular}

Źródło: WHO [8] 
użyć do sporządzenia listy działań (actions), które będą służyć realizacji celów, najpierw szczegółowych, a następnie głównych.

Działania stanowią element [15], który pozwala na wykazanie się kreatywnością przez głównych uczestników systemu. Jeśli osiągnięty zostanie konsens dotyczący celów głównych oraz szczegółowych strategii, następuje faza doboru narzędzi osiągania tych celów. Warto przy tym zauważyć, że w praktyce planowania strategicznego działania często zajmują miejsce celów, głównie szczegółowych. Powszechnym błędem bywa uznawanie za cel takich elementów, jak „,wyposażenie placówek w nowoczesne urządzenia”,,zakup nowoczesnej aparatury" itp. Tymczasem wymienione przykłady są działaniami (actions), które mają służyć osiąganiu przyjętych celów (np. poprawie jakości wykrywania nowotworów).

Wybór działań w strategii jest w pewnym stopniu zależny od warunków panujących w danym kraju lub nawet w regionie, co powoduje, że niekiedy strategie krajowe definiują odmienne działania dla różnych regionów. Istnieje jednak pewna pula działań, które są powtarzającym się elementem wielu strategii. Światowa Organizacja Zdrowia podzieliła te pule klasycznych działań z zakresu strategii zwalczania nowotworów na 4 obszary: zapobieganie i wczesne wykrywanie, rozpoznawanie, leczenie i opieka paliatywna, oraz 3 zakresy, w zależności od zamożności kraju i poziomu rozwoju (tab. II).

W uzupełnieniu do listy działań w strategiach należy rozważyć wskazanie podmiotów, społeczności lub organizacji, które będą odpowiedzialne za ich uruchomienie i przeprowadzenie. Podmioty te powinny być predysponowane do realizacji lub przejęcia przewodzącej roli w realizacji zadań, w zależności od swojego potencjału i możliwości oddziaływania. Wzmocnienie takich podmiotów i ich wyposażenie w nowe możliwości jest jednym z potencjalnych kierunków oddziaływania.

Uzupełnieniem strategicznych dokumentów bywa także harmonogram i informacje o zasobach przeznaczonych na realizację strategii, sposób prowadzenia nadzoru nad całym procesem, struktura monitorowania wyników i komunikacji ze społeczeństwem.

\section{Podsumowanie}

Pojęcie strategia w kontekście zwalczania nowotworów używane jest wymiennie z pojęciem plan lub program, zgodnie z terminologią WHO czy CDC $[12,29]$. Niezależnie od nazw istnieje pewien kanon składowych elementów tego typu dokumentów, obejmujący ocenę stanu, docelową wizję i program działań wraz z rolami, zasobami i mechanizmami kontrolnymi.

Międzynarodowe doświadczenia wskazują, że tworzenie strategii zwalczania nowotworów jest w Europie powszechne. Różne są jednak akcenty w tych strategiach oraz odmienny sposób ich oddziaływania. Doświadczenia innych krajów wskazują, że w Polsce należy opracować szeroką i ogólną strategię, która wskaże kierunki i przypisze role w osiąganiu celów. Jako element tej szerokiej strategii powinien zostać opracowany plan zwalczania chorób nowotworowych, który stanowiłby uzupełnienie rutynowych działań, np. Narodowego Funduszu Zdrowia lub samorządów terytorialnych, i był nakierowany na uzupełnianie braków oraz wspomaganie pożądanych kierunków zmian.

\section{Dr n. med. Adam Kozierkiewicz}

ul. Drawska 14e/32, 02-202 Warszawa

e-mail:akozierkiewicz@wp.pl

\section{Piśmiennictwo}

1. Chandler AD Jr. The Visible Hand. The Belknap Press of Harvard University Press, Cambridge and London 1977.

2. Andrews KR. The concept of corporate strategy. Irwin, Homewood, 1971

3. KoontzH, O'Donnell C. Management (8th ed.). New York:McGraw-Hill, 1988.

4. World Health Assembly 58. Cancer prevention and control. http://www. who.int/cancer/media/news/WHA58\%2022-en.pdf

5. C. O.T. E. Communities. Communication From The Commission To The Parliament on Action Against Cancer: European Partnership. European Commission, Brussels 2009.

6. European Partnership for Action Against Cancer. http://www.epaac eu/national-cancer-plans.

7. Union for International Cancer Control-Global Cancer Control. http:// //www.uicc.org/homepage.

8. World Health Organisation. National Cancer Control Programmes. Policies and Managerial Guidelines. Health \& Development Networks, Geneve 2002.

9. Kaplan S, Norton D. Strategiczna karta wyników. Jak przełożyć strategie na działanie. Warszawa: Państwowe Wydawnictwo Naukowe, 2002.

10. Kaplan S, Norton D. The strategy - focused organization. Boston: Harvard Business School Press, 2001.

11. Kiełczewski S. Zarzadzanie strategiczne. Wrocław: Akademia Ekonomiczna, 2000.

12. World Health Organisation. Cancer control: knowledge into action WHO guide for effective programmes, module 1. Geneve: World Health Organization, 2006.

13. Atun R, Ogawa T, Martin-Moreno J. Analysis of National Cancer Control Programmes in Europe. London: Imperial College, 2009.

14. Reich MR, Cooper DM. PolicyMaker:Computer-Assisted Political Analysis, Software and Manual. Brookline: PoliMap, 1995-2000.

15. Kozierkiewicz A. Restrukturyzacja zakładów opiekizdrowotnej:przewodnik przygotowania projektu. Warszawa: Ministerstwo Zdrowia, 2011.

16. Miller GA. The magical number seven, plus or minus two: Some limits on our capacity for processing information. Psychol Rev 1956; 63: $81-97$.

17. Doll R, Payne P, Waterhouse JAH. Cancer Incidence in Five Continents T. I. Berlin-Heidelberg-New York: Springer-Verlag, 1966.

18. Parkin DM Bray F. Evaluation of data quality in the cancer registry: principles and methods. II. Completeness. Eur J Cancer 2009; 45: 756-764.

19. Ministry of Health. Cancer in New Zealand: Trends and projections. Wellington: Ministry of Health, 2002.

20. GLOBOCAN. Cancer Incidence and Mortality Worldwide in 2008. Lyon: IARC, 2008.

21. Curado MP, Edwards B, Shin HR, Storm H, Ferlay J, Heanue M, Boyle P. Cancer Incidence in Five Continents. T. 9. Lyon: IARC Scientific Publications, 2007.

22. American Cancer Society. Cancer Prevention \& Early Detection Fact \& Figures. Atlanta: American Cancer Society, 2010.

23. Zatoński W, Didkowska J, Wojciechowska U. Epidemiologia chorób nowotworowych w Europie Środkowej i Wschodniej w porównaniu z Europą Zachodnią i Polską. Pol Przegl Chir 2009; 81: 808-837.

24. European Network for Cancer Registries. The suite of Stata (Version 8.0) macros for short-term predictions by Tadek Dyba and Timo Hakulinen of the Finnish Cancer registry. http://www.encr.com.fr/stata-macros1.htm.

25. Wojciechowska U, Didkowska J, Zatoński W. Nowotwory złośliwe w Polsce w 2008 roku. Warszawa: Krajowy Rejestr Nowotworów, 2010.

26. Didkowska J, Wojciechowska U, ZatońskiW. Nowotworyzłośliwe w Polsce w 2009 roku. Warszawa: Centrum Onkologii — Instytut im. M. Skłodowskiej-Curie, 2011.

27. Krzakowski M. Onkologia kliniczna - uwarunkowania jakości postepowania. Nowotwory J Oncol 2010; 60;453-455.

28. Nieburg HE. Cancer prevention \& control strategy: Resolution adopted by the 58th World Health Assembly. Cancer Detect Prev 2005; 29: 403-404.

29. $C D C P$, Guidance for Comprehensive Cancer Control Planning. Volume 1 Guidelines, Division of Cancer Prevention and Control, Centers for Disease Control and Prevention, 4770 Buford Highway, NE, Atlanta, GA 30341, 2002. 